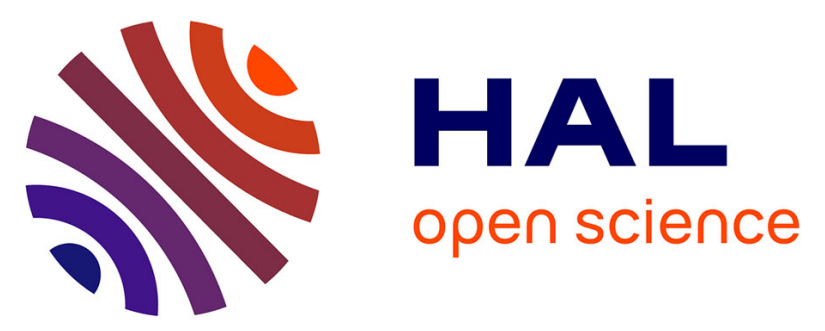

\title{
Hemodynamic Performances and Clinical Outcomes in Patients Undergoing Valve-in-Valve Versus Native Transcatheter Aortic Valve Implantation
}

Mariama Akodad, Alexandra Meilhac, Thierry Lefèvre, Guillaume Cayla, Benoit Lattuca, Cécile Autissier, Claire Duflos, Thomas Gandet, Jean-Christophe Macia, Delphine Delseny, et al.

\section{To cite this version:}

Mariama Akodad, Alexandra Meilhac, Thierry Lefèvre, Guillaume Cayla, Benoit Lattuca, et al.. Hemodynamic Performances and Clinical Outcomes in Patients Undergoing Valve-in-Valve Versus Native Transcatheter Aortic Valve Implantation. American Journal of Cardiology, 2019, 124 (1), pp.90-97. 10.1016/j.amjcard.2019.04.009 . hal-02126715

\section{HAL Id: hal-02126715 \\ https://hal.science/hal-02126715}

Submitted on 11 May 2020

HAL is a multi-disciplinary open access archive for the deposit and dissemination of scientific research documents, whether they are published or not. The documents may come from teaching and research institutions in France or abroad, or from public or private research centers.
L'archive ouverte pluridisciplinaire HAL, est destinée au dépôt et à la diffusion de documents scientifiques de niveau recherche, publiés ou non, émanant des établissements d'enseignement et de recherche français ou étrangers, des laboratoires publics ou privés. 


\title{
Hemodynamic Performances and Clinical Outcomes in Patients Undergoing Valve-in-Valve Versus Native Transcatheter Aortic Valve Implantation
}

\author{
Mariama Akodad, MD ${ }^{\mathrm{a}, \mathrm{b}}$, Alexandra Meilhac, $\mathrm{MD}^{\mathrm{a}}$, Thierry Lefèvre, $\mathrm{MD}^{\mathrm{c}}$, \\ Guillaume Cayla, $\mathrm{MD}, \mathrm{PhD}^{\mathrm{d}}$, Benoit Lattuca, $\mathrm{MD}^{\mathrm{d}}$, Cécile Autissier, $\mathrm{MD}^{\mathrm{e}}$, Claire Duflos, $\mathrm{MD}, \mathrm{PhD}^{\mathrm{e}}$, \\ Thomas Gandet, $\mathrm{MD}^{\mathrm{f}}$, Jean-Christophe Macia, $\mathrm{MD}^{\mathrm{a}}$, Delphine Delseny, $\mathrm{MD}^{\mathrm{a}}$, \\ Francois Roubille, MD, $\mathrm{PhD}^{\mathrm{a}, \mathrm{b}}$, Eric Maupas, $\mathrm{MD}^{\mathrm{g}}$, Laurent Schmutz, $\mathrm{MD}^{\mathrm{d}}$, Christophe Piot, $\mathrm{MD}^{\mathrm{h}}$, \\ Frédéric Targosz, $\mathrm{MD}^{\mathrm{i}}$, Gabriel Robert, $\mathrm{MD}^{\mathrm{j}}$, François Rivalland, $\mathrm{MD}^{\mathrm{k}}$, Bernard Albat, $\mathrm{MD}, \mathrm{PhD}^{\mathrm{f}}$, \\ Bernard Chevalier, $\mathrm{MD}^{\mathrm{c}}$, and Florence Leclercq, $\mathrm{MD}, \mathrm{PhD}^{\mathrm{a}, \mathrm{b}, *}$
}

\begin{abstract}
Valve-in-valve (ViV) transcatheter aortic valve implantation (TAVI) emerged has a less invasive treatment than surgery for patients with degenerated bioprosthesis. However, few data are currently available regarding results of $\mathrm{ViV}$ versus $\mathrm{TAVI}$ in native aortic valve. We aimed to compare hemodynamic performances and 1-year outcomes between patients who underwent ViV procedure and patients who underwent non-ViV TAVI. This bicentric study included all patients who underwent aortic ViV procedure for surgical bioprosthetic aortic failure between 2013 and 2017. All patients who underwent TAVI were included in the analysis during the same period. $\mathrm{ViV}$ and non- $\mathrm{ViV}$ patients were matched with 1:2 ratio according to size, type of TAVI device, age ( \pm 5 years), sex, and STS score. Primary end point was hemodynamic performance including mean aortic gradient and aortic regurgitation at 1-year follow-up. A total of 132 patients were included, 49 in the ViV group and 83 in the non-ViV group. Mean age was $82.8 \pm 5.9$ years, $55.3 \%$ were female. Mean STS score was $5.2 \% \pm$ 3.1\%. Self-expandable valves were implanted in $78.8 \%$ of patients. At 1-year follow-up, aortic mean gradient was significantly higher in ViV group $(18.1 \pm 9.4 \mathrm{~mm} \mathbf{H g}$ vs $11.4 \pm 5.4 \mathrm{~mm}$ $\mathrm{Hg} ; \mathrm{p}<0.0001)$ and $17(38.6 \%)$ patients had a mean aortic gradient $\geq 20 \mathrm{~mm} \mathrm{Hg}$ vs $6(7.8 \%)$ in the non-ViV group $(p=0.0001)$. Aortic regurgitation $>$ grade 2 were similar in both groups $(p=0.71)$. In the ViV group, new pacemaker implantation was less frequent $(p=0.01)$ and coronary occlusions occurred only in $\mathrm{ViV}$ group $(n=2$ [4.1\%]). At 1-year follow-up, 3 patients $(2.3 \%)$ died from cardiac cause, $1(2.1 \%)$ in the ViV group vs $2(2.4 \%)$ in the nonViV group $(p=0.9)$. There was no stroke. In conclusion, compared with TAVI in native aortic stenosis, ViV appears as a safe and feasible strategy in patients with impaired bioprosthesis. As 1-year hemodynamic performances seem better in native TAVI procedure, long-term follow-up should be assessed to determinate the impact of residual stenosis on outcomes and durability.
\end{abstract}

The standard of care of severe aortic valvular disease remains surgical valve replacement and bioprosthesis are favored to mechanical valves in patients $>60$ years old,

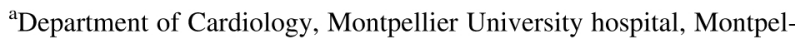
lier University, France; ${ }^{b}$ PhyMedExp, University of Montpellier, Montpellier, France; ' Department of Interventional Cardiology, Hôpital Privé Jacques Cartier, Massy, France; ${ }^{d}$ Department of Cardiology, Nîmes University hospital, Montpellier University, France; ${ }^{\mathrm{c} D e p a r t m e n t}$ of Medical Information, Montpellier University hospital, Montpellier University, France; ${ }^{\mathrm{f}}$ Department of Cardiovascular Surgery, Montpellier University hospital, Montpellier University, France; ${ }^{\mathrm{g}}$ Department of Cardiology, Clinique des Franciscaines, Nîmes, France; ${ }^{\mathrm{h}}$ Department of Cardiology, Clinique du Millénaire, Montpellier, France; 'Department of Cardiology, Perpignan hospital, France; ${ }^{j}$ Department of Cardiology, Clinique Saint Pierre, Perpignan, France; and ${ }^{\mathrm{k}}$ Department of Cardiology, Clinique du Parc, Montpellier, France. Manuscript received January 8, 2019; revised manuscript received and accepted April 1, 2019.

*Corresponding author: Tél: +33467336216; fax: +33467336196.

E-mail addresses: leclercq.florence@club-internet.fr;

f-leclercq@chu-montpellier.fr (F. Leclercq). regarding to their less thrombogenicity. Despite improvements in devices, bioprosthesis durability is limited with a risk of structural degeneration with restenosis, regurgitation or both within 10 to 20 years. ${ }^{2-4}$ In aortic position, degeneration rate reaches $60 \%$ to $70 \%$ of patients $<65$ years old at 20 years follow-up and approximately twice less in patients $\geq 65$ years old. ${ }^{5-7}$ Reoperation for failed surgical valves carries substantial morbidity and mortality risks. ${ }^{8-10}$ Recently, transcatheter aortic valve implantation (TAVI) was considered as a reasonable alternative to surgery in patients with native symptomatic severe aortic stenosis contraindicated to surgery, at high or intermediate surgical risk in case of feasible transfemoral approach. ${ }^{11-17}$ In this context, considering the high risk of cardiac surgery in patients with degenerated bioprosthesis aortic valve, valve-in-valve (ViV) TAVI recently emerged as a promising less invasive treatment. Indeed, the PARTNER 2 Valve-in-Valve Registry showed excellent results of $\mathrm{ViV}$ procedures regarding to outcomes with a $2.7 \%$ 30-day mortality and a $12.4 \%$ 1-year mortality as well as good hemodynamic performances with 
a mean aortic gradient of $17.6 \mathrm{~mm} \mathrm{Hg}$ and less than $2 \%$ significant aortic regurgitation (AR). ${ }^{18}$ Similar results were found in the VIVID Registry including 459 patients with ViV TAVI. ${ }^{19}$ However, few data are currently available comparing aortic ViV to TAVI. The objectives of this study were therefore to compare hemodynamic performances and clinical outcomes in patients who underwent aortic ViV procedure to TAVI in native aortic stenosis.

\section{Methods}

This retrospective bicentric study included all patients who underwent aortic ViV procedure for bioprosthetic aortic failure between 2013 and 2017 at Montpellier University Hospital (France) and at Massy Hospital (France) after heart team decision. To compare this ViV population with patients who underwent TAVI for non-ViV procedure, all patients who underwent TAVI for native aortic valve stenosis (mean aortic valve gradient $\geq 40 \mathrm{~mm} \mathrm{Hg}$, maximal transaortic velocity $\geq 4 \mathrm{~m} / \mathrm{s}$ or aortic valve area $\leq 1 \mathrm{~cm}^{2}$ ) during the same period in the same center were reviewed to be matched with ViV patients according to predefined criteria, with a 2:1 matching ratio. Matching criteria were STS score $(<4 \%, 4$ to $10 \%,>10 \%$ ), size, type (self-expandable [BE] vs balloon-expandable [SE]), generation of TAVI device, age ( \pm 5 years), sex, and center of implantation. If all the matching criteria were not respected, the choice of the optimal matched patient was performed according to the following algorithm (1) main respected criteria were size, type, and generation of TAVI device; (2) if both age and sex were not possible to match, age criterion was a priority; (3) if age and/or sex were not matched, we used the closer matched body surface area $\left(+/-0.1 \mathrm{~m}^{2}\right)$; (4) if there was not 2:1 matched ratio, only one patient was matched. Exclusion criteria were transaortic, transapical approaches, death within the first month after the procedure for hemodynamic assessment in both groups and bicuspid valves in the nonViV group. Bioprosthesis degeneration was defined according to 2 consensus statements edited in 2017 and 2018. , $^{70}$ Three types of structural bioprosthesis dysfunctions were defined: stenosis, regurgitation, or combined: (1) stenosis type was defined by mean aortic gradient $>20 \mathrm{~mm} \mathrm{Hg}$ and/ or increasing in mean aortic gradient $>10 \mathrm{~mm} \mathrm{Hg}$ from baseline; (2) regurgitation type was defined as an intraprosthesis regurgitation more than moderate; (3) combined type as a combination of moderate stenosis and moderate regurgitation.

Concerning procedural characteristics, a systematic ECG-gated, contrast-enhanced multiple-slice helical computed tomography (MSCT) (General Electric LightSpeed VCT or ICT Philips), was performed in all patients for annulus sizing, aortic measurements, and vascular access assessment before TAVI. Valve size was selected according to manufacturer's recommendations after determination of internal annulus area, perimeter, and mean diameter of bioprosthesis and of the virtual annulus on MSCT. Both BE (Edwards Sapien XT or Sapien 3, Edwards Lifesciences LLC, Irvine, California) and SE (Corevalve or EvolutR, Medtronic, Inc., Minneapolis, Minnesota) devices were implanted. All patients underwent TAVI procedure under general or local anesthesia and the transfemoral access was performed through a surgical cutdown or a percutaneous approach with Prostar or double Proglide (Abbott Vascular Devices, Redwood City, California) closure technique according to the operator's choice. ${ }^{21}$ Alternative access sites (carotid, subclavian, apical, and aortic) were considered only in case of unsuitable iliofemoral anatomy. Subclavian, apical, and aortic route were excluded from the analysis. Indeed, in our center, if femoral access is not suitable, carotid approach is the second access used; subclavian, direct aortic, or apical routes are very rare and may include patients at higher risk. The optimal position of the valve was checked by fluoroscopy and a rapid pacing (160 to $200 \mathrm{beats} / \mathrm{min}$ ) was triggered during the implantation of BE devices as previously described. ${ }^{22} \mathrm{~A}$ final control was performed by aortography and transthoracic echocardiography (TTE).

Primary end point was hemodynamic performance of the prosthesis including mean aortic gradient and AR assessed by TTE at 1 year follow-up. Quantification of AR was performed using TTE and classified as none, mild (grade 1), moderate (grade 2), and severe (grade 3 ) with combined criteria as recommended for native valves. ${ }^{23}$

Secondary end points were hemodynamic performance at 1-month, major cardiovascular events including stroke, myocardial infarction, heart failure, rehospitalization for cardiac causes at 1 month and 1 year as well as 1 -year mortality according to VARC-2 criteria. ${ }^{24}$

Patient's baseline characteristics, procedural details, and in-hospital outcomes were collected from a prospective TAVI database after written consent. One-month and 1 -year follow-up data were obtained from medical records or from patients' cardiologist. No additional testing or biological samples were specifically required for this study as TTE were systematically performed for all patients after TAVI at 1-month and 1-year. TTE were performed by patients' referents cardiologists. Parameters systematically collected were left ventricular ejection fraction (LVEF) $(\%)$, mean aortic transprosthetic gradient (mm Hg), presence, and grades of intra- or periprosthetic AR, mitral regurgitation, and sPAP. All data were centralized and reviewed by one physician expert in echocardiography.

The protocol was approved by the local ethics committee and the institutional regulatory authorities, and conduced according to the principles of the Declaration of Helsinki.

Patients' characteristics were presented using mean \pm SD for continuous variables and frequencies and proportions for categorical variables. Baseline characteristics were compared between the 2 groups using univariate conditional logistic regression, using the group as the dependent variable. To determine the effect of the group on the procedures choices and on clinical outcomes during follow-up, univariate regressions using the group as the independent variable were performed: linear for continuous outcomes, logistic for dichotomous outcomes, and polytomous for categorical outcomes with more than 2 classes. A p value $<0.05$ reached the statistical significance. Statistical analysis was performed by the department of medical information of Montpellier University Hospital using SAS, v.9, statistical software (SAS Institute, Cary, North Carolina). 


\section{Results}

Between January 2013 and June 2017, 2,547 patients underwent a TAVI procedure in both centers. In the population assessed for inclusion (2,092 patients), 79 (3.8\%) died at 1-month, 1 in the ViV group (2\%) and $78(3.8 \%)$ in the non-ViV group, and were excluded from the hemodynamic analysis at 1-month and 1-year. A total of 132 patients were enrolled in the study: 49 in the ViV group and 83 in the non-ViV group. In the 132 patients, 30-day analysis was performed in $131(99 \%)$ and 1-year analysis in $121(92 \%)$ patients (Figure 1).

In the whole study population, mean age was $82.8 \pm$ 5.9 years, $55.3 \%$ (73 patients) were female, mean STSscore was $5.2 \% \pm 3.1 \%$. Grade III-IV NYHA dyspnea concerned 69 patients $(52.3 \%)$ and 20 patients $(15.2 \%)$ presented acute heart failure. Baseline characteristics are presented in Table 1.

In the ViV group, at baseline, 29 patients $(59.2 \%)$ had stenosis of the bioprosthesis, $10(20.4 \%)$ had AR and 9 (18.4\%) presented both. Only 1 patient $(2.0 \%)$ had a patient-prosthesis mismatch. Regarding clinical variables, patients from the ViV group had a significant higher mean logistic EuroSCORE $(29.8 \% \pm 15.4 \%$ vs $13.7 \% \pm 9.0 \%$, $\mathrm{p}<0.001)$ and were younger than patients in the non-ViV group $(81.08 \pm 7.34$ vs $83.86 \pm 4.60, p=0.003)$.

The transfemoral access was the main access route. Predilatation was significantly less frequent in the ViV group
$(11.8 \%$ vs $44.3 \%, p=0.003)$. SE valves were more frequently selected than BE valves. Procedural characteristics are presented in Table 2. Procedural success rate was $100 \%$. There was a good balance between first and last generation TAVI devices in both groups. At 1-year follow-up, mean aortic gradient was significantly higher in ViV group: $18.1 \pm 9.4 \mathrm{~mm} \mathrm{Hg}$ versus $11.4 \pm 5.4 \mathrm{~mm} \mathrm{Hg}$ in the non-ViV group, $\mathrm{p}<0.0001$ (Figure 2). In the $\mathrm{ViV}$ group, 17 patients $(38.6 \%)$ had a mean aortic gradient $\geq 20 \mathrm{~mm} \mathrm{Hg}$ versus 6 patients $(7.8 \%)$ in the non-ViV group $(\mathrm{p}=0.0001)$. Paravalvular regurgitations $\geq$ grade 2 were similar in both groups $(6.8 \%$ in the $\mathrm{ViV}$ group vs $5.2 \%$ in the non-ViV group, $\mathrm{p}=0.71$ ) (Figure 3a).

At 1-month, aortic gradient was significantly higher in the ViV group $(18.3 \pm 11.0$ vs $11.6 \pm 9.3 \mathrm{~mm} \mathrm{Hg}$, respectively, $p=0.0004$ ) with a higher rate of patients with mean aortic gradient $\geq 20 \mathrm{~mm} \mathrm{Hg}$ in this group. Significant AR rate were similar in both groups (Figures 2 and 3b, Table 3).

In the $\mathrm{ViV}$ group, mean aortic gradient $\geq 20 \mathrm{~mm} \mathrm{Hg}$, both at 1-month and 1-year, was mainly associated with SE valves (17 patients (94.4\%) and 11 patients (64.7\%), respectively), whereas in the non-ViV group, these high gradients included predominantly $\mathrm{BE}$ valves (5 patients $(71.4 \%)$ and 4 patients $(66.7 \%)$, respectively.

One-month outcomes are presented in Table 3. Eleven patients $(8.4 \%)$ were hospitalized for cardiac event (2 patients, $4.2 \%$ in the ViV group versus $9(10.8 \%$ in the non-ViV group, $\mathrm{p}=0.2), 4(3.1 \%)$ had myocardial

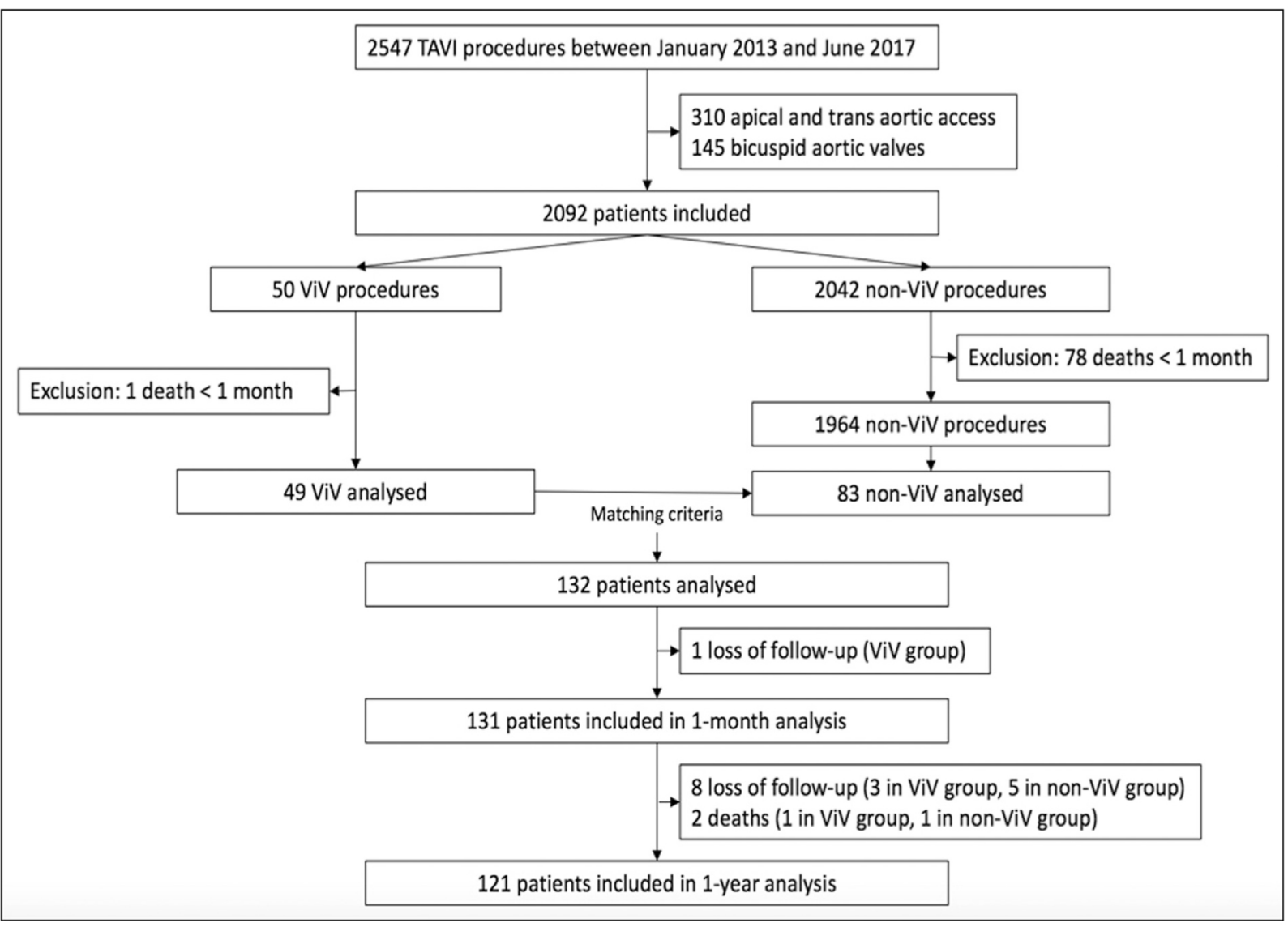

Figure 1. Flowchart. 
Baseline characteristics

\begin{tabular}{|c|c|c|c|c|}
\hline & ViV group $(n=49)$ & Non-ViV group $(\mathrm{n}=83)$ & OR $[95 \% \mathrm{CI}]$ & $\mathrm{p}$ Value \\
\hline \multicolumn{5}{|l|}{ Clinical variables } \\
\hline Age (years) & $81.08 \pm 7.34$ & $83.86 \pm 4.60$ & $0,82[0,72-0,93]$ & 0.003 \\
\hline Female sex & $20(40.8 \%)$ & $53(63.9 \%)$ & - & 0.99 \\
\hline Logistic EuroSCORE (\%) & $29.77 \pm 15.41$ & $13.72 \pm 8.95$ & $1,2[1,1-1,31]$ & $<0.001$ \\
\hline STS-Score $(\%)$ & $5.64 \pm 3.85$ & $4.89 \pm 2.44$ & $1,48[1,07-2,04]$ & 0.01 \\
\hline STS-Score & & & & 0.99 \\
\hline$<4 \%$ & $18(36.7 \%)$ & $29(34.9 \%)$ & - & \\
\hline $4 \%-10 \%$ & $28(57.1 \%)$ & $51(61.4 \%)$ & - & \\
\hline$>10 \%$ & $3(6.1 \%)$ & $3(3.6 \%)$ & - & \\
\hline BMI $\left(\mathrm{kg} / \mathrm{m}^{2}\right)$ & $26 \pm 5$ & $26 \pm 5$ & $1[0,92-1,1]$ & 0.92 \\
\hline $\operatorname{BSA}\left(\mathrm{m}^{2}\right)$ & $1.81 \pm 0.22$ & $1.73 \pm 0.19$ & $40,21[2,51-645,54]$ & 0.009 \\
\hline Hypertension & $26(53.1 \%)$ & $51(61.4 \%)$ & $0,69[0,33-1,44]$ & 0.33 \\
\hline Diabetes mellitus & $14(29.2 \%)$ & $18(21.9 \%)$ & $1,67[0,67-4,16]$ & 0.27 \\
\hline Dyslipidemia & $20(40.8 \%)$ & $31(37.3 \%)$ & $1,15[0,56-2,35]$ & 0.71 \\
\hline Active smokers & $4(8.2 \%)$ & 0 & - & 0.99 \\
\hline Coronary disease & $27(55.1 \%)$ & $51(61.4 \%)$ & $0,74[0,35-1,55]$ & 0.42 \\
\hline Prior PCI & $9(18.4 \%)$ & $24(28.9 \%)$ & $0,61[0,26-1,41]$ & 0.24 \\
\hline Prior $\mathrm{CABG}$ & $13(26.5 \%)$ & $8(9.6 \%)$ & $3,03[1,13-8,12]$ & 0.02 \\
\hline Creatinine $(\mu \mathrm{mol} / \mathrm{l})$ & $112.20 \pm 41.92$ & $105.57 \pm 68.02$ & $1[1-1,01]$ & 0.47 \\
\hline Chronic renal disease* & $46(93.9 \%)$ & $80(96.4 \%)$ & $0,42[0,07-2,64]$ & 0.35 \\
\hline Dialysis & 0 & $2(2.4 \%)$ & - & 0.99 \\
\hline Chronic respiratory disease & $4(8.2 \%)$ & $13(15.7 \%)$ & $0,48[0,15-1,55]$ & 0.22 \\
\hline Prior stroke & $2(4.1 \%)$ & $4(4.8 \%)$ & $0,84[0,15-4,77]$ & 1 \\
\hline PAD & $4(8.2 \%)$ & $20(24.1 \%)$ & $0,22[0,06-0,79]$ & 0.02 \\
\hline Supra ventricular arrhythmia & $11(22.9 \%)$ & $18(21.7 \%)$ & $1,07[0,44-2,62]$ & 0.88 \\
\hline Prior PPM & $4(8.2 \%)$ & $5(6.0 \%)$ & $1,3[0,31-5,42]$ & 0.71 \\
\hline \multicolumn{5}{|l|}{ Symptoms } \\
\hline NYHA 3-4 & $25(51.0 \%)$ & $44(53.0 \%)$ & $0,94[0,47-1,88]$ & 0.86 \\
\hline Acute heart failure & $11(22.4 \%)$ & $9(10.8 \%)$ & $2,79[0,94-8,3]$ & 0.06 \\
\hline Angor & $1(2.0 \%)$ & $8(9.6 \%)$ & $0,19[0,02-1,54]$ & 0.12 \\
\hline Syncope & 0 & $4(4.8 \%)$ & - & 0.99 \\
\hline Prior BAV & 0 & $2(2.4 \%)$ & - & 0.99 \\
\hline \multicolumn{5}{|l|}{ Echographic variables } \\
\hline $\operatorname{LVEF}(\%)$ & $53.71 \pm 12.33$ & $58 \pm 10.18$ & $0,95[0,91-0,99]$ & 0.009 \\
\hline $\mathrm{LVEF} \leq 30 \%$ & $5(10.2 \%)$ & $3(3.7 \%)$ & $4,33[0,82-22,82]$ & 0.08 \\
\hline Mean aortic initial gradient $(\mathrm{mm} \mathrm{Hg})$ & $45.14 \pm 17.66$ & $47.10 \pm 13.02$ & $0,99[0,97-1,02]$ & 0.68 \\
\hline Aortic regurgitation $\geq$ grade 2 & $15(31.2 \%)$ & $7(8.7 \%)$ & $6,58[1,85-23,46]$ & 0.004 \\
\hline Mitral regurgitation $\geq$ grade 2 & $14(28.6 \%)$ & $7(9.2 \%)$ & $4,74[1,53-14,71]$ & 0.007 \\
\hline $\mathrm{sPAP} \geq 60 \mathrm{~mm} \mathrm{Hg}$ & $13(26.5 \%)$ & $5(6.1 \%)$ & $6,21[1,72-22,39]$ & 0.005 \\
\hline
\end{tabular}

Values are mean $\pm \mathrm{SD}$ or $\mathrm{n}(\%)$.

$\mathrm{BAV}=$ balloon aortic valvuloplasty; $\mathrm{BMI}=$ body mass index; $\mathrm{BSA}=$ body surface area; $\mathrm{CABG}=$ coronary artery bypass grafting; NYHA = New York Heart Association; $\mathrm{PAD}=$ peripheral arterial disease; $\mathrm{PCI}=$ percutaneous coronary intervention; $\mathrm{PPM}=$ permanent pacemaker; $\mathrm{sPAP}=$ systolic pulmonary arterial pressure; $\mathrm{STS}=$ society of thoracic surgery.

* eGFR $<60 \mathrm{ml} / \mathrm{min} / 1.73 \mathrm{~m}^{2}$.Odds Ratios (OR) and $\mathrm{p}$ values are computed using univariate conditional logistic regressions predicting the Viv or non-Viv group. For some matching variables and for variables with null profiles, OR could not be computed.

infarction (2: $4.17 \%$ in the $\mathrm{ViV}$ group vs $2: 2.4 \%$ in the non-ViV group, $\mathrm{p}=0.58)$. Permanent pacemaker was implanted in $26(19.9 \%)$ patients $(3: 6.3 \%$ in the ViV group vs 23: $27.7 \%$ in the non-ViV group, $\mathrm{p}=0.007)$. At 1 -year follow-up, 3 patients $(2.3 \%)$ died from cardiac cause, 1 $(2.1 \%)$ in the $\mathrm{ViV}$ group versus $2(2.4 \%)$ in the non-ViV group $(\mathrm{p}=0.9)$. There was no stroke.

\section{Discussion}

This study describes a matched comparison of aortic $\mathrm{ViV}$ and TAVI procedure for native aortic stenosis regarding to hemodynamic performance and outcomes with 3 main findings: (1) At baseline, ViV patients were at higher risk profile than patients from non-ViV group. (2) Mean aortic gradient was significantly higher at 1-month and 1year in patient who underwent $\mathrm{ViV}$ procedure with comparable AR rate in both groups. (3) ViV procedure was feasible and safe in terms of 1-month and 1-year clinical outcomes. Matched criteria with a potential impact on hemodynamic performance and outcomes were selected to limit bias allowing a comparison between ViV and TAVI for native aortic stenosis in this study. Indeed, the size, the type, and generation of TAVI device may impact the results on hemodynamic performance as previously described. ${ }^{18,19}$ Regarding to prognosis, age, sex, and STS score were selected as matching criteria, as there were previously described as prognostic factors in TAVI. ${ }^{18,19}$ Despite these 
Table 2

Procedural characteristics

\begin{tabular}{|c|c|c|c|c|}
\hline Variable & Total $(n=132)$ & ViV group $(n=49)$ & Non-ViV group $(n=83)$ & $\mathrm{p}$ Value \\
\hline Approach & & & & 0.63 \\
\hline Transfemoral & $125(94.7 \%)$ & $47(95.9 \%)$ & $78(93.9 \%)$ & \\
\hline Transcarotid & $7(5.3 \%)$ & $2(4.1 \%)$ & $5(6.0 \%)$ & \\
\hline Device type & & & & 0.86 \\
\hline Balloon-expandable (BE) & $28(21.2 \%)$ & $10(20.4 \%)$ & $18(21.7 \%)$ & \\
\hline Self-expandable (SE) & $104(78.8 \%)$ & $39(79.6 \%)$ & $65(78.3 \%)$ & \\
\hline Implanted BE device size & & & & 0.97 \\
\hline $20 \mathrm{~mm}$ & $2(1.5 \%)$ & $1(2.0 \%)$ & $1(1.2 \%)$ & \\
\hline $23 \mathrm{~mm}$ & $20(15.1 \%)$ & $7(14.3 \%)$ & $13(15.7 \%)$ & \\
\hline $26 \mathrm{~mm}$ & $6(4.5 \%)$ & $2(4.1 \%)$ & $4(4.8 \%)$ & \\
\hline $29 \mathrm{~mm}$ & 0 & 0 & 0 & \\
\hline Implanted SE device size & & & & 0.91 \\
\hline $23 \mathrm{~mm}$ & $62(47.0 \%)$ & $25(51.0 \%)$ & $37(44.6 \%)$ & \\
\hline $26 \mathrm{~mm}$ & $33(25.0 \%)$ & $11(22.4 \%)$ & $22(26.5 \%)$ & \\
\hline $29 \mathrm{~mm}$ & $9(6.8 \%)$ & $3(6.1 \%)$ & $6(7.2 \%)$ & \\
\hline $31 \mathrm{~mm}$ & 0 & 0 & 0 & \\
\hline Predilatation* & $31(32.6 \%)$ & $4(11.8 \%)$ & $27(44.3 \%)$ & 0.003 \\
\hline Postdilatation $^{\dagger}$ & $11(12.2 \%)$ & $5(15.6 \%)$ & $6(10.3 \%)$ & 0.47 \\
\hline Successful procedure & $132(100.0 \%)$ & $49(100.0 \%)$ & $83(100.0 \%)$ & - \\
\hline
\end{tabular}

Values are mean $\pm \mathrm{SD}$ or $\mathrm{n}(\%)$.

$\mathrm{BE}=$ balloon expandable; $\mathrm{SE}=$ self-expandable.

$\mathrm{p}$ Values were computed using univariate generalized linear models predicting each procedural characteristic and using the $\mathrm{ViV}$ or non-ViV group as the independent factor.

$* \mathrm{n}=95$ patients.

${ }^{\dagger} \mathrm{n}=90$ patients.

adjustments, patients from the ViV group had significantly a higher logistic EuroSCORE, related to history of surgery. However, Logistic EuroSCORE is not recommended for risk stratification in patients who underwent TAVI procedure. ${ }^{11}$ Both groups were different regarding to body surface area, rate of previous coronary artery bypass grafting, peripheral arterial disease, significant AR, mitral regurgitation, pulmonary hypertension, and LVEF without impact on long-term outcomes in our study. These findings are consistent with the study of Tuzcu et al comparing for the first time ViV patients with patients who underwent TAVI for aortic native valve stenosis. ${ }^{25}$

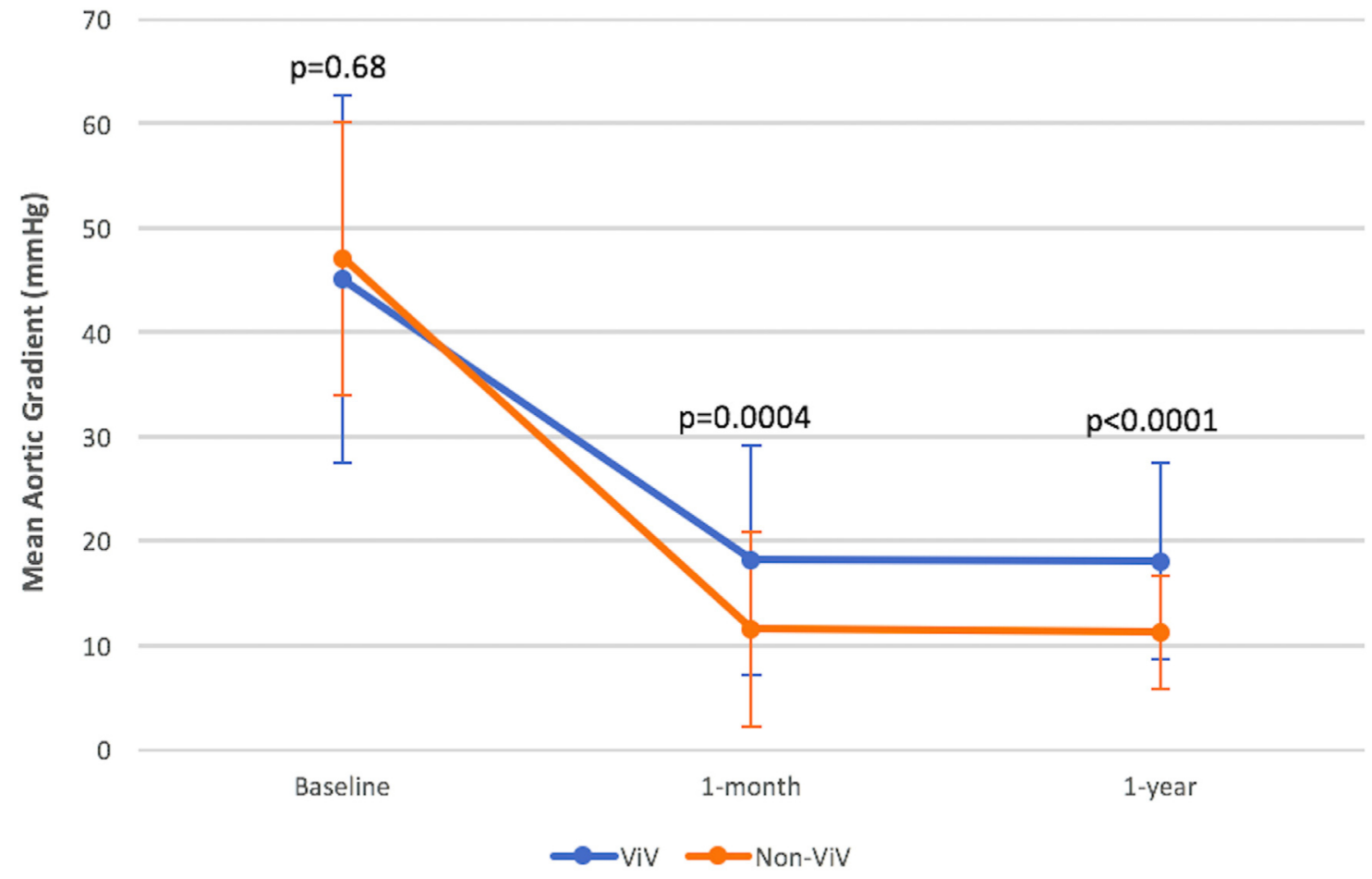

Figure 2. Mean aortic gradient between ViV and non-ViV group. 

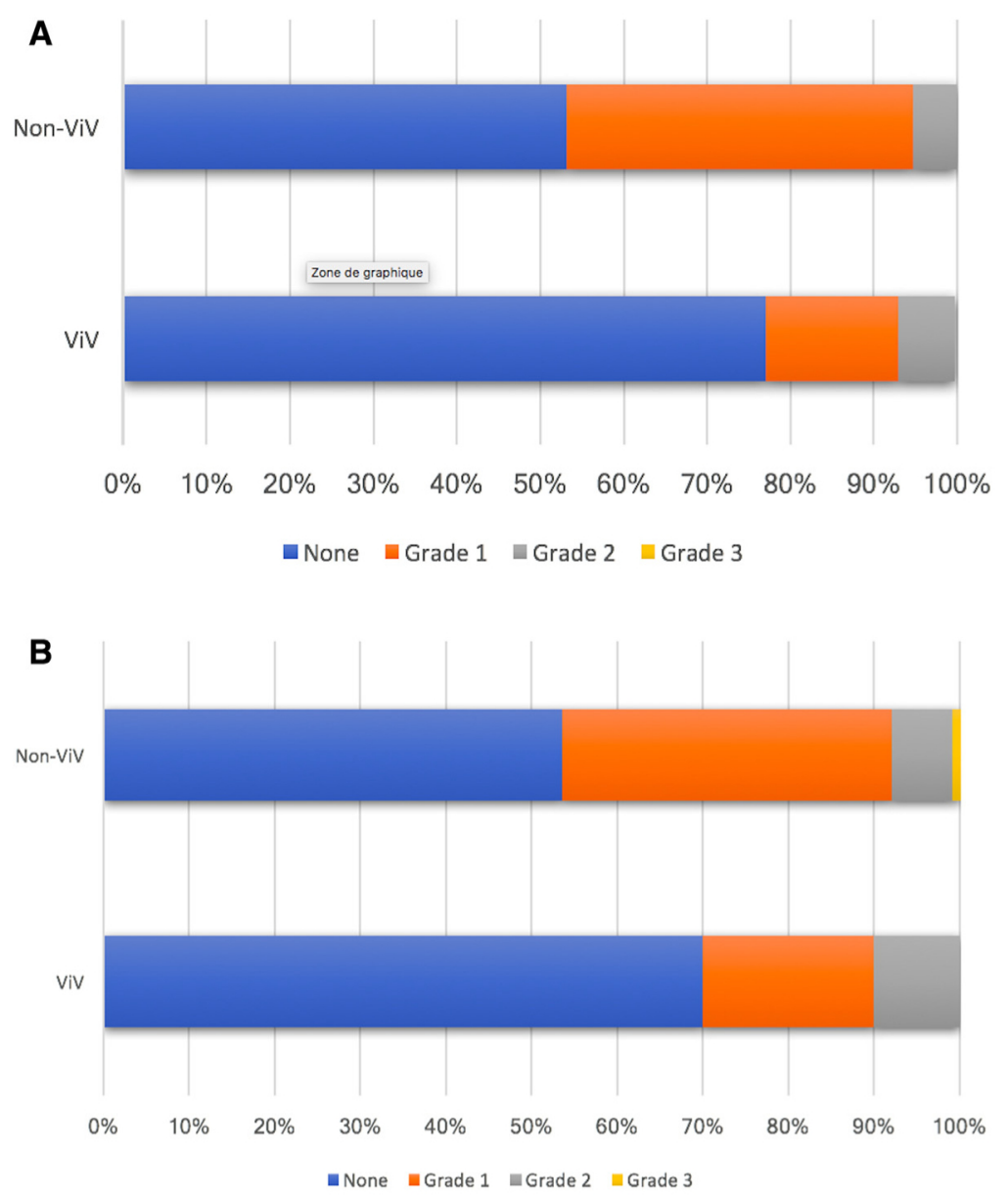

Figure 3.a. Paravalvular regurgitations at 1-year. b. Paravalvular regurgitations at 1-month.

In this study, mean aortic gradient was significantly higher at 1-month and 1-year in patients who underwent $\mathrm{ViV}$ procedure in comparison with patients who underwent TAVI for aortic native stenosis with a mean gradient at $18.09 \mathrm{~mm} \mathrm{Hg}$ and $1 / 3$ of patients with a mean gradient $>20 \mathrm{~mm} \mathrm{Hg}$. Indeed, although the size of the TAVI device was a matching criterion, the effective aortic annulus is well-known as smaller in patients with previous surgical bioprosthesis. ${ }^{26}$ These results are consistent with the literature, indeed, in the American ViV registry, 1-year mean aortic gradient was $17.6 \mathrm{~mm} \mathrm{Hg}$ and $25 \%$ of patients had a mean aortic gradient $>20 \mathrm{~mm} \mathrm{Hg} .{ }^{18}$ Usual risk factors of elevated mean gradient after ViV procedure are smaller surgical bioprosthesis, stenosis type of degenerated bioprosthesis, and level of implantation.

Moreover, hemodynamic profile remained stable at 1 -month and 1-year in our population consistent with results from others studies. ${ }^{18,26}$ Finally, in our study, significant AR was comparable between $\mathrm{ViV}$ group and non-ViV group, with a low incidence of $A R \geq$ grade $2(10.42 \%)$ comparable with results from ViV registries. ${ }^{18,19,26}$ Mean gradient is constantly higher in ViV procedure in comparison to TAVI for native aortic stenosis in the literature..$^{8,19,25-28}$ However, results of our study may suggest a higher implantation depth with a supra-annular position of TAVI devices in surgical bioprosthesis to improve hemodynamic results. ${ }^{29}$
In our study, 1-month and 1-year mortality were $2 \%$ and $2.08 \%$ in the $\mathrm{ViV}$ group, comparable with the mortality rates in the non- $\mathrm{ViV}$ group. The mortality rates in our study are lower than previously described in the literature for patients who underwent aortic ViV procedure. ${ }^{18,19,26}$ These results may be explained in one hand by the relatively low surgical risk of our population suggested by the mean STS score around $5.6 \%$ and in contrast by a learning curve and improvements in the technique suggested by the relatively recent study including patients since 2013 . A learning curve in $\mathrm{ViV}$ procedure was suggested for the first time by Webb et al. ${ }^{30}$ Patients in the ViV group experienced a higher rate of coronary occlusion than patients implanted with TAVI for native aortic valve stenosis, as previously described. ${ }^{19}$ A careful examination of preprocedural MSCT should be performed to limit this risk. In our study, patients from ViV group experienced a low rate of pacemaker $(6.1 \%)$ as previously reported. Indeed, in registries, ViV patients reach a low rate of pacemaker implantation with a potential protective effect of the rigid annular ring of surgical bioprosthesis on conduction pathways but also because of previous implantation performed after surgery. ${ }^{18,25}$ In our study, although mean aortic gradient was significantly higher in ViV patients, 1-year mortality was not higher in comparison with patients who underwent TAVI for native aortic valve stenosis. These results are consistent with the 


\begin{tabular}{|c|c|c|c|c|}
\hline & Total $(\mathrm{n}=132)$ & ViV group $(n=49)$ & Non-ViV group $(\mathrm{n}=83)$ & $\mathrm{p}$ Value \\
\hline \multicolumn{5}{|l|}{ Clinical outcomes } \\
\hline Death & 0 & 0 & 0 & - \\
\hline Need for second device & 0 & 0 & 0 & - \\
\hline Conversion to surgical aortic valve replacement (SAVR) & 0 & 0 & 0 & - \\
\hline Annulus rupture & 0 & 0 & 0 & - \\
\hline Coronary occlusion & $2(1.5 \%)$ & $2(4.1 \%)$ & 0 & - \\
\hline Need for PPM & $24(18.2 \%)$ & $3(6.1 \%)$ & $21(25.3 \%)$ & 0.01 \\
\hline Major vascular complication* & $15(11.4 \%)$ & $4(8.2 \%)$ & $11(13.3 \%)$ & 0.38 \\
\hline Stroke & $2(1.5 \%)$ & $1(2.0 \%)$ & $1(1.2 \%)$ & 0.71 \\
\hline Acute renal failure & 0 & 0 & 0 & - \\
\hline Rehospitalization for cardiac cause & $5(3.8 \%)$ & $1(2.1 \%)$ & $4(4.8 \%)$ & 0.44 \\
\hline \multicolumn{5}{|l|}{ Treatment } \\
\hline Single antiplatelet therapy & $30(23.4 \%)$ & $12(26.1 \%)$ & $18(21.9 \%)$ & 0.60 \\
\hline Double antiplatelet therapy & $82(64.1 \%)$ & $25(54.4 \%)$ & $57(69.5 \%)$ & 0.09 \\
\hline Oral anticoagulation alone & $26(20.3 \%)$ & $9(19.6 \%)$ & $17(20.7 \%)$ & 0.88 \\
\hline Oral anticoagulation and single antiplatelet therapy & $14(10.9 \%)$ & $5(10.9 \%)$ & $9(10.9 \%)$ & 0.99 \\
\hline Oral anticoagulation and double antiplatelet therapy & $3(2.3 \%)$ & $1(2.2 \%)$ & $2(2.4 \%)$ & 0.92 \\
\hline \multicolumn{5}{|l|}{ Hemodynamic outcomes } \\
\hline Mean aortic gradient $(\mathrm{mm} \mathrm{Hg})$ & $13.4 \pm 8.9$ & $18.3 \pm 10.9$ & $11.6 \pm 9.3$ & $<0.0001$ \\
\hline Mean aortic gradient $\geq 20 \mathrm{~mm} \mathrm{Hg}$ & $25(18.9 \%)$ & $18(37.5 \%)$ & $7(8.4 \%)$ & 0.0002 \\
\hline Paravalvular regurgitation $\geq$ grade 2 & $12(9.2 \%)$ & $5(10.4 \%)$ & $7(8.4 \%)$ & 0.71 \\
\hline
\end{tabular}

Values are mean $\pm \mathrm{SD}$ or $\mathrm{n}(\%)$.

$\mathrm{PPM}=$ permanent pacemaker.

* Defined by ischemia or major bleeding BARC $\geq 2$.p-values were computed using univariate generalized linear models predicting each outcome and using the $\mathrm{ViV}$ or non- $\mathrm{ViV}$ group as the independent factor.

literature with no impact of mean aortic gradient $>20 \mathrm{~mm}$ $\mathrm{Hg}$ on 1 -year mortality in $\mathrm{ViV}$ patients. ${ }^{26}$ Moreover, in FRANCE 2 registry, 1-year mortality was similar between ViV procedures and TAVI in native aortic stenosis. ${ }^{28}$ Our study may have some limitations. The first limit of this study is the presence of potential confounder factors despite the utilization of matching criteria. However, despite selecting age as a matching criterion, the mean age was different between the 2 groups but age-adjusted analyses performed in all the following regression models has not change our univariate results (data not shown). Patients from the ViVgroup had also higher rates of previous mitral regurgitation, pulmonary hypertension, lower LVEF, and previous CABG rising the higher risk of this population without clinical significance. Secondarily, despite the enrolment of patients in 2 centers, the sample size remains relatively small with few patients who underwent ViV procedure. Finally, the statistical powerful of this study is limited with a low incidence of outcomes in each group.

In conclusion, Aortic ViV procedure for degenerated bioprosthesis, performed in patients with intermediate risk profile, appears feasible, safe, and effective with comparable clinical outcomes than in patients who underwent TAVI in native aortic stenosis. However, hemodynamic results are slightly different, in favor of TAVI for native aortic stenosis. Long-term follow-up should be assessed to determinate the impact of residual stenosis on outcomes and durability.
1. Brown JM, O’Brien SM, Wu C, Sikora JAH, Griffith BP, Gammie JS. Isolated aortic valve replacement in North America comprising 108,687 patients in 10 years: changes in risks, valve types, and outcomes in the Society of Thoracic Surgeons National Database. J Thorac Cardiovasc Surg 2009;137:82-90.

2. Jamieson WR, Munro AI, Miyagishima RT, Allen P, Burr LH, Tyers GF. Carpentier-Edwards standard porcine bioprosthesis: clinical performance to seventeen years. Ann Thorac Surg 1995;60:999-1006.

3. Jamieson WR, Miyagishima RT, Burr LH, Lichtenstein SV, Fradet GJ, Janusz MT. Carpentier-Edwards porcine bioprostheses: clinical performance assessed by actual analysis. J Heart Valve Dis 2000;9:530-535.

4. Ruel M, Kulik A, Rubens FD, Bédard P, Masters RG, Pipe AL, Mesana TG. Late incidence and determinants of reoperation in patients with prosthetic heart valves. Eur J Cardiothorac Surg 2004;25: 364-370.

5. Yun KL, Miller DC, Moore KA, Mitchell RS, Oyer PE, Stinson EB, Robbins RC, Reitz BA, Shumway NE. Durability of the Hancock MO bioprosthesis compared with standard aortic valve bioprostheses. Ann Thorac Surg 1995;60(2 Suppl):S221-S228.

6. Mykén PSU, Bech-Hansen O. A 20-year experience of 1712 patients with the Biocor porcine bioprosthesis. I Thorac Cardiovasc Surg 2009; 137:76-81.

7. Dvir D, Bourguignon T, Otto CM, Hahn RT, Rosenhek R, Webb JG, Treede H, Sarano ME, Feldman T, Wijeysundera HC, Topilsky Y, Aupart M, Reardon MJ, Mackensen B, Szeto WY, Kornowski R, Gammie JS, Yoganathan AP, Arbel Y, Borger MA, Simonato M, Reisman M, Makkar RR, Abizaid A, McCabe JM, Dahle G, Aldrea GS, Leipsic J, Pibarot P, Moat NE, Mack MJ, Kappetein P, Leon MB. Standardized definition of structural valve degeneration for surgical and transcatheter bioprosthetic aortic valves. Circulation 2018;137:388-399.

8. Jones JM, O'kane H, Gladstone DJ, Sarsam MA, Campalani G, MacGowan SW, Cleland J, Cran GW. Repeat heart valve surgery: risk factors for operative mortality. J Thorac Cardiovasc Surg 2001;122: 913-918.

9. Maganti M, Rao V, Armstrong S, Feindel CM, Scully HE, David TE. Redo valvular surgery in elderly patients. Ann Thorac Surg 2009;87: 521-525.

10. Leontyev S, Borger MA, Davierwala P, Walther T, Lehmann S, Kempfert J, Mohr FW. Redo aortic valve surgery: early and late outcomes. Ann Thorac Surg 2011;91:1120-1126. 
11. Baumgartner H, Falk V, Bax JJ, De Bonis M, Hamm C, Holm PJ, Iung B, Lancellotti P, Lansac E, Rodriguez Munoz R, Rosenhek R, Sjögren J, Tornos Mas P, Vahanian A, Walther T, Wendler O, Windecker S, Zamorano JL. 2017 ESC/EACTS Guidelines for the management of valvular heart disease. Eur Heart J 2017;38:2739-2791 .

12. Leon MB, Smith CR, Mack M, Miller DC, Moses JW, Svensson LG, Tuzcu EM, Webb JG, Fontana GP, Makkar RR, Brown DL, Block PC, Guyton RA, Pichard AD, Bavaria JE, Herrmann HC, Douglas PS, Petersen JL, Akin JJ, Anderson WN, Wang D, Pocock S. Transcatheter aortic-valve implantation for aortic stenosis in patients who cannot undergo surgery. N Engl J Med 2010;363:1597-1607.

13. Leon MB, Smith CR, Mack MJ, Makkar RR, Svensson LG, Kodali SK, Thourani VH, Tuzcu EM, Miller DC, Herrmann HC, Doshi D, Cohen DJ, Pichard AD, Kapadia S, Dewey T, Babaliaros V, Szeto WY, Williams MR, Kereiakes D, Zajarias A, Greason KL, Whisenant BK, Hodson RW, Moses JW, Trento A, Brown DL, Fearon WF, Pibarot P, Hahn RT, Jaber WA, Anderson WN, Alu MC, Webb JG. Transcatheter or surgical aortic-valve replacement in intermediate-risk patients. N Engl J Med 2016;374:1609-1620.

14. Adams DH, Popma JJ, Reardon MJ, Yakubov SJ, Coselli JS, Deeb GM, Gleason TG, Buchbinder M, Hermiller J, Keiman NS, Chetcuti S, Heiser J, Merhi W, Zorn G, Tadros P, Robinson N, Petrossian G, Hughes GC, Harrisson K, Conte J, Maini B, Mumtaz M, Chenoweth S, Oh JK. Transcatheter aortic-valve replacement with a self-expanding prosthesis. N Engl J Med 2014;370:1790-1798.

15. Smith CR, Leon MB, Mack MJ, Miller DC, Moses JW, Svensson LG, Tuzcu EM, Webb JG, Fontana GP, Makkar RR, Williams M, Dewey T, Kapadia S, Babaliaros V, Thourani VH, Corso P, Pichard AD, Bavaria JE, Herrmann HC, Akin JJ, Anderson WN, Wang D, Pocock SJ. Transcatheter versus surgical aortic-valve replacement in high-risk patients. N Engl J Med 2011;364:2187-2198.

16. Thourani VH, Kodali S, Makkar RR, Herrmann HC, Williams M, Babaliaros V, Smalling R, Lim S, Malaisrie SC, Kapadia S, Szeto WY, Greason KL, Kereiakes D, Ailawadi G, Whisenant BK, Devireddy C, Leipsic J, Hahn RT, Pibarot P, Weissman NJ, Jaber WA, Cohen DJ, Suri R, Tuzcu EM, Svensson LG, Webb JG, Moses JW, Mck MJ, Miller DC, Smith CR, Alu MC, Partavaneni R, D'Agostino $\mathrm{RB}$, Leon MB. Transcatheter aortic valve replacement versus surgical valve replacement in intermediate-risk patients: a propensity score analysis. Lancet 2016;387:2218-2225.

17. Reardon MJ, Van Mieghem NM, Popma JJ, Kleiman NS, Søndergaard L, Mumtaz M, Adams DH, Deeb GM, Maini B, Gada H, Chetcuti S, Gleason T, Heiser J, Lange R, Merhi W, Oh JK, Olsen PS, Piazza N, Williams M, Windecker S, Uakubov SJ, Grube E, Makkar RR, Lee JS, Conte J, Vang E, Nguyen H, Chang Y, Mugglin AS, Serruys PWJC, Kappetein AP. Surgical or transcatheter aortic-valve replacement in intermediate-risk patients. N Engl J Med 2017;376:1321-1331.

18. Webb JG, Mack MJ, White JM, Dvir D, Blanke P, Herrmann HC, Leipsic J, Kodali SK, Makkar RR, Miller DC, Pibarot P, Pichard A, Satler LF, Svensson L, Alu MC, Suri RM, Leon MB. Transcatheter aortic valve implantation within degenerated aortic surgical bioprostheses: PARTNER 2 valve-in-valve registry. J Am Coll Cardiol 2017;69:2253-2262.

19. Dvir D, Webb JG, Bleiziffer S, Pasic M, Waksman R, Kodali S, Barbanti M, Latib A, Schaefer U, Rodès-Cabau J, Treede H, Piazza N, Hildick-Smith D, Himbert D, Walther T, Hengstenberg C, Nissen H, Bekeredjian R, Presbitero P, Ferrari E, Segev A, De Weger A, Windecker S, Moat NE, Napodano M, Wilbring M, Cerillo AG, Brecker S, Tchetche D, Lefèvre T, De Marco F, Fiorina C, Petronio AS, Teles RC, Testa L, Laborde JC, Leon MB, Kornowki R. Transcatheter aortic valve implantation in failed bioprosthetic surgical valves. JAMA 2014;312:162-170.

20. Capodanno D, Petronio AS, Prendergast B, Eltchaninoff H, Vahanian A, Modine T, Lancellotti P, Sondergaard L, Ludman PF, Tamburino C, Piazza N, Hancock J, Mehilli J, Byrne RA, Baumbach A, Kappetein AP, Windecker S, Bax J, Haude M. Standardized definitions of structural deterioration and valve failure in assessing long-term durability of transcatheter and surgical aortic bioprosthetic valves: a consensus statement from the European Association of Percutaneous Cardiovascular Interventions (EAPCI) endorsed by the European Society of Cardiology (ESC) and the European Association for Cardio-Thoracic Surgery (EACTS). Eur J CardioThorac Surg 2017;52:408-417.

21. Toggweiler S, Gurvitch R, Leipsic J, Wood DA, Willson AB, Binder RK, Cheung A, ye J, Webb JG. Percutaneous aortic valve replacement: vascular outcomes with a fully percutaneous procedure. I Am Coll Cardiol 2012;59:113-118.

22. Nijhoff F, Agostoni P, Samim M, Ramjankhan FZ, Kluin J, Doevendans PA, Stella PR. Optimisation of transcatheter aortic balloonexpandable valve deployment: the two-step inflation technique. EuroIntervention 2013;9:555-563.

23. Lancellotti P, Tribouilloy C, Hagendorff A, Popescu BA, Edvardsen T, Pierard LA, Badano L, Zamorano JL. Recommendations for the echocardiographic assessment of native valvular regurgitation: an executive summary from the European Association of Cardiovascular Imaging. Eur Heart J Cardiovasc Imaging 2013;14:611-644.

24. Kappetein AP, Head SJ, Généreux P, Piazza N, Mieghem NM van, Blackstone EH, Brott TG, Cohen DJ, Cutlip DE, Van Es GA, Hahn RT, Kirtane AJ, Krucoff MW, Kodali S, Mack MJ, Mehran R, RodèsCabau J, Vranckx P, Webb JG, Windecker S, Serruys PW, Leon MB. Updated standardized endpoint definitions for transcatheter aortic valve implantation: the Valve Academic Research Consortium-2 consensus document. J Thorac Cardiovasc Surg 2013;145:6-23.

25. Tuzcu EM, Kapadia SR, Vemulapalli S, Carroll JD, Holmes DR, Mack MJ, Thourani VH, Grover FL, Brennan JM, Suri RM, Dai D, Svensson LG. Transcatheter aortic valve replacement of failed surgically implanted bioprostheses. J Am Coll Cardiol 2018;72:370-382.

26. Deeb GM, Chetcuti SJ, Reardon MJ, Patel HJ, Grossman PM, Schreiber T, Forrest JK, Bajwa TK, O’Hair DP, Petrossian G, Robinson N, Katz S, Hartman A, Dauerman HL, Schmoker J, Khabbaz K, Watson DR, Yakubov SJ, Oh JK, Li S, Keiman NS, Adams DH, Popma JJ. 1-Year results in patients undergoing transcatheter aortic valve replacement with failed surgical bioprostheses. JACC Cardiovasc Interv 2017;10:1034-1044.

27. Bleiziffer S, Erlebach M, Simonato M, Pibarot P, Webb J, Capek L, Windecker S, George I, Sinning JM, Horlick E, Napodano M, Holzhey DM, Petursson P, Cerillo A, Bonaros N, Ferrari E, Cohen MG, Baquero G, Jones TL, Kalra A, Reardon MJ, Chhatriwalla A, Ribeiro VG, Alnasser S, Van Mieghem NM, Rustenbach CJ, Schofer J, Garcia S, Zeus T, Champagnac D, Bekeredjian R, Kornowki R, Lange R, Dvir D. Incidence, predictors and clinical outcomes of residual stenosis after aortic valve-in-valve. Heart Br Card Soc 2018;104:828-834.

28. Gilard M, Eltchaninoff H, Donzeau-Gouge P, Chevreul K, Fajadet J, Leprince P, Leguerrier A, Lievre M, Prat A, Teiger E, Lefevre T, Himbert D, Tchetche D, Carrié D, Albat B, Cribier A, Rioufol G, Sudre A, Blanchard D, Collet F, Dos Santos P, Meneveau N, Tirouvanziam A, Caussin C, Guyon P, Boschat J, Le Breton H, Collart F, Houel R, Delpine S, Souteyrand G, Faverau X, Ohlmann P, Doisy V, Grollier G, GOmmeaux A, Claudel JP, Bourlon F, Bertrand B, Van Belle E, Laskar M. Late outcomes of transcatheter aortic valve replacement in high-risk patients. J Am Coll Cardiol 2016;68:1637-1647.

29. Simonato M, Webb J, Kornowski R, Vahanian A, Frerker C, Nissen H, Bleiziffer S, Duncan A, Rodès-Cabau J, Attizzani GF, Horlick E? Latib A, Bekeredjian R, Barbanti M, Lefevre T, Cerillo A, Hernandez JM, Bruschi G, Spargias K, Iadanza A, Brecker S, Palma JH, Finkelstein A, Abdel-Wahab M, Lemos P, Petronio AS, Champagnac D, Sinning JM, Salizzoni S, Napodano M, Fiorina C, Marzocchi A, Leon M, Dvir D. Transcatheter replacement of failed bioprosthetic valves: large multicenter assessment of the effect of implantation depth on hemodynamics after aortic valve-in-valve. Circ Cardiovasc Interv 2016;9: e003651.

30. Webb JG, Wood DA, Ye J, Gurvitch R, Masson J-B, Rodés-Cabau J, Osten M, Horlick E, Wendler O, Dumont E, Carere RG, Wijesinghe $\mathrm{N}$, Nietlispach F, Johnson M, Thompson CR, Moss R, Leipsic J, Munt B, Lichtenstein SV, Cheung A. Transcatheter valve-in-valve implantation for failed bioprosthetic heart valves. Circulation 2010; 121:1848-1857. 